\title{
COMPRESSIVE STRENGTH BEHAVIOUR OF CONCRETE PRODUCED USING OKIGWE RED LUMP STONE AS COARSE AGGREGATE
}

\author{
CHIOMA TEMITOPE GLORIA AWODIJI ${ }^{1 *}$, CHINEDU PAUL EZEGO ${ }^{1}$, DAVIS \\ OGBONNA ONWUKA ${ }^{1}$, STANLEY EMEKA IWUOHA ${ }^{1}$
}

${ }^{I}$ Department of Civil Engineering, Federal University of Technology, Owerri, P.M.B 1526. Imo State, Nigeria

\begin{abstract}
This study was carried out in order to ascertain if the Okigwe red lump stone, found in South-eastern Nigeria, could be used as coarse aggregate in making structural concrete. The maximum compressive strength values, obtained at 28 days for red lump stone concrete were $13.72 \mathrm{~N} / \mathrm{mm}^{2}$ at w/c ratio of 0.53 for mix ratio $1: 2: 4$ and $8.74 \mathrm{~N} / \mathrm{mm}^{2}$ for mix ratio 1:3:6, at w/c ratio of 0.55 . These values were not up to $20 \mathrm{~N} / \mathrm{mm}^{2}$ which is the ACI 318 (1995) recommendation for structural concrete. Therefore, Okigwe red lump stone must not be used in making structural concrete using mixes 1:2:4 and 1:3:6.
\end{abstract}

Keywords: Okigwe red lump stone (ORLS), compressive strength, concrete

\section{INTRODUCTION}

Concrete is one of the most used construction material in civil engineering works and modern buildings. This is because it is good in resisting compressive forces and fire, and can also be formed to take any desired shape. It consist primarily of cement, fine aggregates, coarse aggregates, and water in predefined mix proportions. Sometimes, chemical or natural additives are included in its production, when concrete of special qualities (strength and durability) are required. The aggregates in concrete, acts as filler materials that make up between $70 \%-80 \%$ of the volume of normal concrete [1].

Their properties to a great extent, determine the properties of concrete. In order to produce concrete of high quality, aggregates has to be free from contaminants such as clay, silts, oil, organic matter and sugar. They must also be long lasting and tough. Otherwise, it should be washed prior to use, because any of these impurities may slow or even stop the hydration process of the cement. Impurities found on aggregates also have the ability to cut down the degree of bond between aggregate particles and mortar [2]. It is always more economical to make use of the smallest allowable quantity of cement and the largest allowable amount of aggregate, in the mix ratio. Other advantages of using aggregates in producing concrete include: improved stability, durability and strength when compared to mortar [3].

According to size, aggregates are classified as either fine or coarse. Fine aggregates are aggregates passing No.4 $(4.75 \mathrm{~mm})$ sieve, and do not pass through the No. $200(75 \mu \mathrm{m})$ sieve [2]. They have a major function in the concrete, which is to serve as filler material. They help to fill up the spaces left open by the interlocking of the coarse aggregates, and are naturally occurring or manufactured construction materials for the production of concrete. Examples of fine aggregates are; river sand, laterite, quarry dust, scoria, blast furnace slag etc. On the other hand, coarse aggregates are aggregates that are retained on the $4.75 \mathrm{~mm}$ British Standard sieves [2]. The

\footnotetext{
* Corresponding author, email: chimbaegbu@yahoo.com

(C) 2018 Alma Mater Publishing House
} 
most commonly used maximum aggregate size is $20 \mathrm{~mm}$. This aggregate play a major role, in giving shape and form to any concrete element cast, and contribute greatly to the overall performance of the element in service. Examples of coarse aggregates are granite chippings, river stones, gravels, limestone, periwinkle shells, palm kernel shells etc.

The properties of any given concrete is influenced by the chemical and physical characteristics of the aggregates used to produce the concrete. The class, appearance and size of any aggregate control the quantity of water required in making concrete. "Aggregate surface texture influences the bond between the aggregate and the cement paste" [2]. A homogenously blended concrete, will usually have elements of its aggregates totally bounded by mortar and this mortar occupies every void between particles. The effects of the interaction between the aggregate and mortar can either increase or reduce the union between them, thereby, affecting the quality of the concrete.

Several researchers have carried out works on coarse aggregate, with respect to their strength properties in concrete. Abdullahi reported that river gravel concrete, experienced the greatest level of workability followed by those made from crushed quartzite and lastly, by those made from granite aggregates [4]. The highest compressive strength recorded for all curing ages was observed from concretes produced using quartzite aggregates with $35 \mathrm{~N} / \mathrm{mm}^{2}$ compressive strength value. Next was the river gravel concrete having compressive strength of $25 \mathrm{~N} / \mathrm{mm}^{2}$. Granite concrete had the least compressive strength at $20 \mathrm{~N} / \mathrm{mm}^{2}$. Tsado tell in his studies, discovered that at low strength of $20 \mathrm{~N} / \mathrm{mm}^{2}$, crushed granite concrete had the largest compressive strength value of $26.45 \mathrm{~N} / \mathrm{mm}^{2}$ [5]. Next to this was limestone concrete with strength value of $26.11 \mathrm{~N} / \mathrm{mm}^{2}$. Lastly, marble concrete had the least strength at $26.03 \mathrm{~N} / \mathrm{mm}^{2}$. At high strengths of $30 \mathrm{~N} / \mathrm{mm}^{2}$, crushed granite concrete experienced the highest strength value of $30.11 \mathrm{~N} / \mathrm{mm}^{2}$. This was followed by that made from marble rock at $29.78 \mathrm{~N} / \mathrm{mm}^{2}$ and limestone concrete at $29.53 \mathrm{~N} / \mathrm{mm}^{2}$.

Ajamu and Ige investigated on how the compressive and flexural strengths of concrete are affected by various sizes of coarse aggregates [6]. They reported that the compressive strength of $13.2 \mathrm{~mm}, 19 \mathrm{~mm}, 25 \mathrm{~mm}$ and $37.5 \mathrm{~mm}$ aggregate sizes were $21.26 \mathrm{~N} / \mathrm{mm}^{2}, 23.41 \mathrm{~N} / \mathrm{mm}^{2}, 23.66 \mathrm{~N} / \mathrm{mm}^{2}$ and $24.3 \mathrm{~N} / \mathrm{mm}^{2}$ respectively. The flexural strengths recorded for these aggregate sizes were $4.93 \mathrm{~N} / \mathrm{mm}^{2}, 4.78 \mathrm{~N} / \mathrm{mm}^{2}, 4.53 \mathrm{~N} / \mathrm{mm}^{2}, 4.49 \mathrm{~N} / \mathrm{mm}^{2}$ and $4.40 \mathrm{~N} / \mathrm{mm}^{2}$ respectively. Yaqub and Bukhari found that for high strength concrete, higher compressive strength values were observed for aggregate size $10 \mathrm{~mm}$ and $5 \mathrm{~mm}$ when compared to other sizes [7]. Aginam reported that concrete made with granite as coarse aggregate had higher compressive strength values than those made with washed and unwashed gravels [8]. Yaqub and Bukhari [7], found that $10 \mathrm{~mm}$ and 5mm aggregates concrete had higher compressive strengths than other sizes of aggregates. Oyewole et al. [9], from their study, reported that as the size of coarse aggregate is minimized, strength of concrete is improved. Xie et al. confirmed the earlier findings by-Oyewole et al. that the compressive strength decreased when the maximum coarse aggregate size was increased $[9,10]$.

Kumar and Krishna [11], stated that cinder based lightweight concrete of 20MPa attained optimum compressive strength with the use of $12.5 \mathrm{~mm}$ aggregate size, while in the making of 30MPa concrete the best 28-day compressive strength was obtained with $10 \mathrm{~mm}$ size aggregates. In a study by Bhikshma [12], they reported that aggregate size of $12.5 \mathrm{~mm}$ gave the highest compressive, splitting tensile and flexural strengths. Compressive strength tests on normal and high strength concrete revealed that the influence of aggregate size on the concrete compressive strength was negligible for strength more than $80 \mathrm{MPa}$ [13]. They further revealed that there was little impact on the modulus of elasticity of concrete made with $10 \mathrm{~mm}$ and $20 \mathrm{~mm}$ aggregates. The compressive strength of gneiss concrete was investigated by Anthony et all [14]. The $10 \mathrm{~mm}$ maximum aggregate size gave a compressive strength of $23.7 \mathrm{~N} / \mathrm{mm}^{2}$. This was higher than that of $14 \mathrm{~mm}$ and $20 \mathrm{~mm}$ sizes, with their compressive strength at $22.0 \mathrm{~N} / \mathrm{mm}^{2}$ and $16.2 \mathrm{~N} / \mathrm{mm}^{2}$ respectively.

Red lump stone found in Okigwe local government area of Imo State Nigeria has gained wide spread use as a coarse aggregatate in concrete production due to the fact that it is very much cheaper than granite chippings, readily available to the locals, and can be locally mined. Its use has resulted to reduced cost of construction. This study is aimed at determining whether it is appropriate for use as coarse aggregate for structural purposes. 


\section{EXPERIMENTAL SETUP}

\subsection{Materials}

Materials used for this study were; portland cement, river sand, granite chippings, red lump stone and water. Portland cement, conforming to British Standard Institution BS 12 (1978) and NIS 444-1:2003 was used in the test. River sand as fine aggregate was obtained locally from Otamiri River at the Federal University of Technology Owerri, Imo State. Average bulk density of river sand was $1656.022 \mathrm{~kg} / \mathrm{m}^{3}$. The red lump stone used was obtained from a quarry site at Ihube, in Okigwe, Imo State of Nigeria. While, granite chippings were also sourced from Okigwe. These coarse aggregates passed through the British Standard sieve size of $20 \mathrm{~mm}$ and had average bulk density values of $1630.924 \mathrm{~kg} / \mathrm{m}^{3}$ and $1706.225 \mathrm{~kg} / \mathrm{m}^{3}$ respectively. Aggregates used for this study fell under the normal weight classification. Water is a major component in the concrete mix. The water used for mixing and curing of the concrete was potable water from Federal University of Technology, Owerri, Imo State, Nigeria.

\subsection{Methods}

\subsubsection{Proportioning of the concrete materials}

In this study, proportioning of the concrete materials was done by weight in kilograms. A total of 10 mix ratios were obtain from the two mix ratios studied (i.e. 1:2:4 and 1:3:6). Each of the mix ratios was kept constant while their water-cement ratios were varied. For mix ratio $1: 2: 4$, water-cement ratio considered were $0.5,0.53,0.55$, 0.58 and 0.60 respectively. For mix ratio $1: 3: 6$, water- cement ratios considered were $0.5,0.53,0.55,0.58$ and 0.62 respectively. These mix ratios were then converted to weights and then used to proportion water, cement, river sand, and granite chippings for the normal concrete (control); and water, cement, river sand and Okigwe red lump stone for the concrete under study. The sand was measured and mixed thoroughly with the cement in an impermeable surface before the granite chipping or red lump stones were added. Water was then added and the whole batch was thouroughly mixed using a shovel. The slump of each concrete mix was measured. Table 1 and Table 2 show the required quantities of each component of concrete materials used for the two mix ratio considered.

Table 1. Mix proportion for concrete cube of 1:2:4 mix ratio.

\begin{tabular}{|l|c|c|c|c|c|}
\hline $\begin{array}{l}\text { Mix } \\
\text { ratio }\end{array}$ & $\begin{array}{c}\text { Water- cement } \\
\text { ratio }\end{array}$ & $\begin{array}{c}\text { Water } \\
(\mathrm{Kg})\end{array}$ & $\begin{array}{c}\text { Cement } \\
(\mathrm{Kg})\end{array}$ & $\begin{array}{c}\text { Sand } \\
(\mathrm{Kg})\end{array}$ & $\begin{array}{c}\text { Coarse Aggregate } \\
(\text { Granite/ORLS })\end{array}$ \\
\hline & 0.50 & 0.64 & 1.29 & 2.57 & 5.14 \\
\hline $1: 2: 4$ & 0.53 & 0.68 & 1.29 & 2.57 & 5.14 \\
\hline & 0.55 & 0.71 & 1.29 & 2.57 & 5.14 \\
\hline & 0.58 & 0.75 & 1.29 & 2.57 & 5.14 \\
\hline & 0.60 & 0.80 & 1.29 & 2.57 & 5.14 \\
\hline
\end{tabular}

Table 2. Mix proportion for concrete cube of 1:3:6 mix ratio.

\begin{tabular}{|l|c|c|c|c|c|}
\hline $\begin{array}{l}\text { Mix } \\
\text { ratio }\end{array}$ & $\begin{array}{c}\text { Water-cement } \\
\text { ratio }\end{array}$ & $\begin{array}{c}\text { Water } \\
(\mathrm{Kg})\end{array}$ & $\begin{array}{c}\text { Cement } \\
(\mathrm{Kg})\end{array}$ & $\begin{array}{c}\text { Sand } \\
(\mathrm{Kg})\end{array}$ & $\begin{array}{c}\text { Coarse Aggregate } \\
\text { (Granite/ORLS) }\end{array}$ \\
\hline & 0.5 & 0.45 & 0.90 & 2.70 & 5.40 \\
\hline $1: 3: 6$ & 0.53 & 0.48 & 0.90 & 2.70 & 5.40 \\
\hline & 0.55 & 0.50 & 0.90 & 2.70 & 5.40 \\
\hline & 0.58 & 0.52 & 0.90 & 2.70 & 5.40 \\
\hline & 0.62 & 0.56 & 0.90 & 2.70 & 5.40 \\
\hline
\end{tabular}

\subsubsection{Preparing and testing of the concrete cube specimen}

The cubic concrete specimen was cast in a steel mould of size $150 \mathrm{~mm}$ x $150 \mathrm{~mm}$ x $150 \mathrm{~mm}$. The mould and its bottom were strongly held together to avoid leakage. Then a layer of engine oil was applied to its inner surface, to make the removal of the specimen easy. A total of 60 (sixty) concrete cubes were cast. 3 concrete cubes were produced for each mix proportions of 1:2:4 and 1:3:6 respectively. Each mould was filled with concrete in three equal layers, with each layer receiving 25 blows with a tapping rod of $25 \mathrm{~mm}$. The top surface of the concrete was smoothened with the help of a trowel and then stored unperturbed for 24hours. They were then demoulded and transferred immediately to curing water tanks at room temperature. The cubes were left to cure for 28 days. Specimen were allowed to dry, weighed and then placed in contact with the sheet of the testing machine where load at a constant rate was applied until cracks occurred. The load that caused the failure was recorded as the crushing load and the value of compressive strength was calculated from equation 1. 


$$
F_{c}=\frac{P}{A}
$$

where: A is cross sectional area of cube specimen $\left(\mathrm{mm}^{2}\right), \mathrm{P}$ - recorded crushing load $(\mathrm{N})$; FC - compressive strength of concrete $\left(\mathrm{N} / \mathrm{mm}^{2}\right)$.

\section{RESULTS AND DISCUSSION}

Workability test in form of slump test was conducted and the results obtained are presented in Figure 1 and Figure 2 .

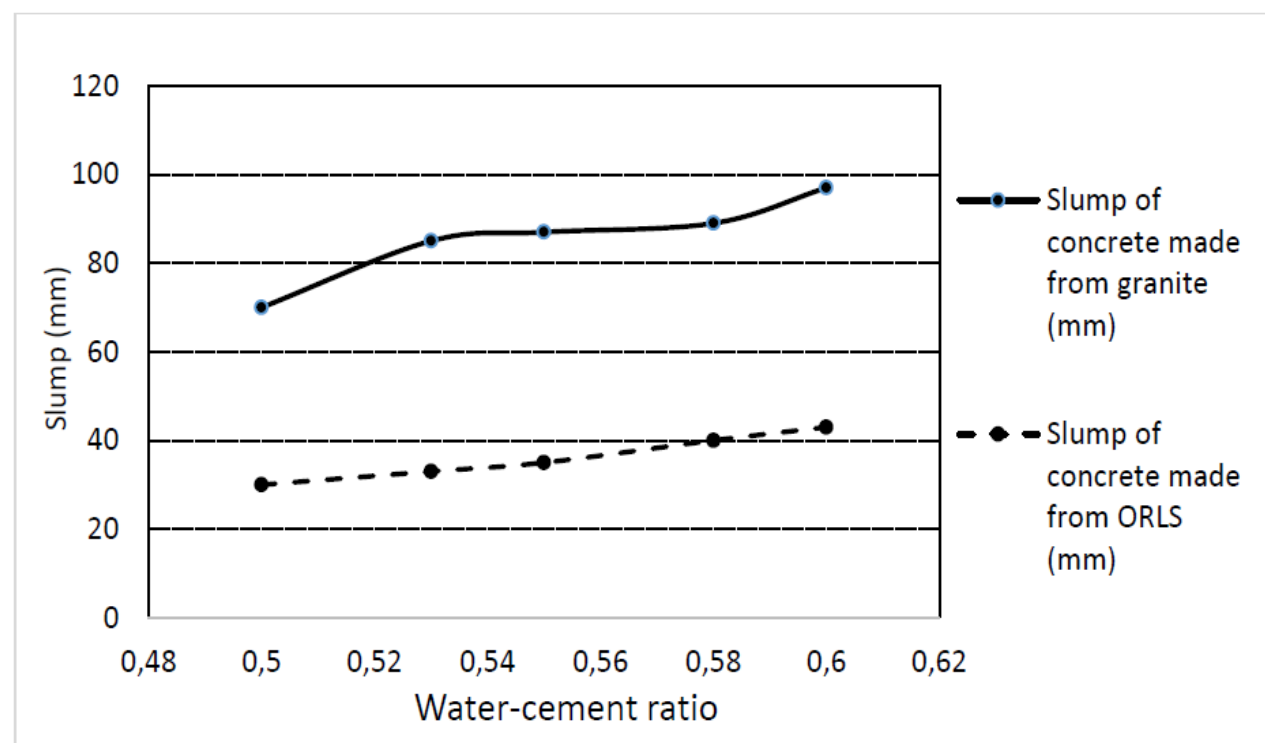

Fig. 1. Slump value for concrete produced from granite chippings/ORLS with mix ratio 1:2:4.

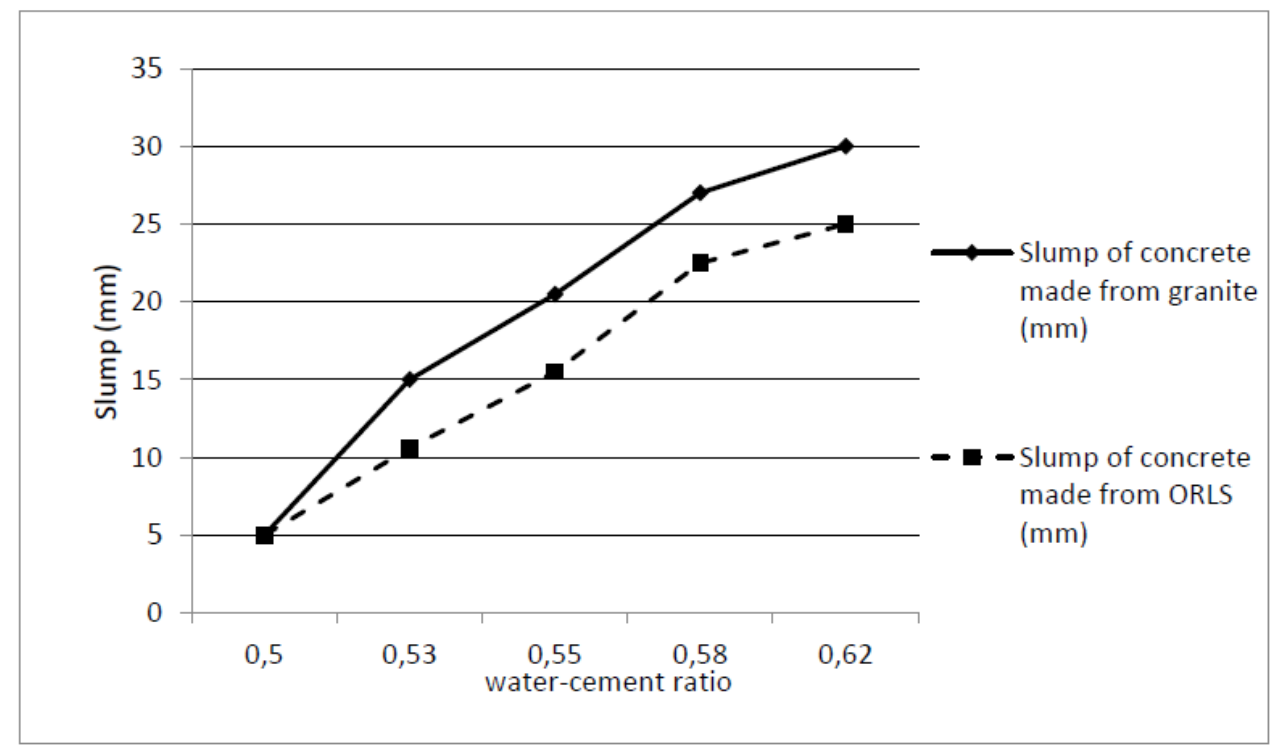

Fig. 2. Slump value for concrete produced from granite chippings/ORLS with mix ratio 1:3:6.

Results of the compressive strength test conducted on concrete made from granite chippings and ORLS are presented on Table 3 to Table 6 . 
Table 3. Compressive strengths at 28 days for ORLS concrete (1:2:4 mix).

\begin{tabular}{|c|c|c|c|c|c|c|c|}
\hline $\begin{array}{l}\text { Water- } \\
\text { cement } \\
\text { ratio }\end{array}$ & Replicates & $\begin{array}{l}\text { Mass } \\
(\mathrm{Kg})\end{array}$ & $\begin{array}{l}\text { Density } \\
\left(\mathrm{Kg} / \mathrm{m}^{3}\right)\end{array}$ & $\begin{array}{l}\text { Average density } \\
\qquad\left(\mathrm{Kg} / \mathrm{m}^{3}\right)\end{array}$ & $\begin{array}{l}\text { Failure load } \\
\qquad(\mathrm{KN})\end{array}$ & $\begin{array}{c}\text { Compressive } \\
\text { strength } \\
\left(\mathrm{N} / \mathrm{mm}^{2}\right)\end{array}$ & $\begin{array}{c}\text { Average } \\
\text { compressive } \\
\text { strength }\left(\mathrm{N} / \mathrm{mm}^{2}\right)\end{array}$ \\
\hline \multirow{3}{*}{0.5} & $\mathrm{~A}$ & 8.45 & 2504 & \multirow{3}{*}{2519} & 232 & 10.31 & \multirow{3}{*}{7.88} \\
\hline & B & 8.65 & 2563 & & 132 & 5.87 & \\
\hline & $\mathrm{C}$ & 8.40 & 2489 & & 168 & 7.47 & \\
\hline \multirow{3}{*}{0.53} & $\mathrm{~A}$ & 8.50 & 2519 & \multirow{3}{*}{2509} & 342 & 15.20 & \multirow{3}{*}{13.72} \\
\hline & B & 8.35 & 2474 & & 228 & 10.13 & \\
\hline & $\mathrm{C}$ & 8.55 & 2533 & & 356 & 15.82 & \\
\hline \multirow{3}{*}{0.55} & A & 8.30 & 2459 & \multirow{3}{*}{2509} & 278 & 12.36 & \multirow{3}{*}{13.16} \\
\hline & B & 8.50 & 2519 & & 322 & 14.31 & \\
\hline & $\mathrm{C}$ & 8.60 & 2548 & & 288 & 12.80 & \\
\hline \multirow{3}{*}{0.58} & A & 8.45 & 2504 & \multirow{3}{*}{2509} & 260 & 11.56 & \multirow{3}{*}{12.74} \\
\hline & B & 8.55 & 2533 & & 328 & 14.58 & \\
\hline & $\mathrm{C}$ & 8.40 & 2489 & & $2 * 72$ & 12.09 & \\
\hline \multirow{3}{*}{0.60} & $\mathrm{~A}$ & 8.25 & 2444 & \multirow{3}{*}{2425} & 274 & 12.18 & \multirow{3}{*}{11.58} \\
\hline & B & 8.10 & 2400 & & 244 & 10.84 & \\
\hline & $\mathrm{C}$ & 8.20 & 2430 & & 264 & 11.73 & \\
\hline
\end{tabular}

Table 4. Compressive strengths at 28 days for granite concrete (1:2:4 mix).

\begin{tabular}{|c|c|c|c|c|c|c|c|}
\hline $\begin{array}{l}\text { Water- } \\
\text { cement } \\
\text { ratio }\end{array}$ & Replicates & $\begin{array}{l}\text { Mass } \\
(\mathrm{Kg})\end{array}$ & $\begin{array}{l}\text { Density } \\
\left(\mathrm{Kg} / \mathrm{m}^{3}\right)\end{array}$ & $\begin{array}{c}\begin{array}{c}\text { Average } \\
\text { density }\end{array} \\
\left(\mathrm{Kg} / \mathrm{m}^{3}\right)\end{array}$ & $\begin{array}{l}\text { Failure } \\
\text { load } \\
(\mathrm{KN})\end{array}$ & $\begin{array}{c}\text { Compressive } \\
\text { strength } \\
\left(\mathrm{N} / \mathrm{mm}^{2}\right)\end{array}$ & $\begin{array}{c}\text { Average } \\
\text { compressive } \\
\text { strength } \\
\left(\mathrm{N} / \mathrm{mm}^{2}\right)\end{array}$ \\
\hline \multirow{3}{*}{0.5} & $\mathrm{~A}$ & 9.00 & 2667 & \multirow{3}{*}{2642} & 562 & 24.98 & \multirow{3}{*}{25.93} \\
\hline & B & 8.55 & 2533 & & 684 & 30.40 & \\
\hline & $\mathrm{C}$ & 9.20 & 2726 & & 504 & 22.40 & \\
\hline \multirow{3}{*}{0.53} & A & 8.90 & 2637 & \multirow{3}{*}{2608} & 378 & 16.80 & \multirow{3}{*}{18.73} \\
\hline & B & 8.50 & 2519 & & 454 & 20.18 & \\
\hline & $\mathrm{C}$ & 9.00 & 2667 & & 432 & 19.20 & \\
\hline \multirow{3}{*}{0.55} & A & 8.50 & 2519 & \multirow{3}{*}{2504} & 278 & 12.36 & \multirow{3}{*}{17.81} \\
\hline & B & 8.40 & 2489 & & 390 & 17.33 & \\
\hline & $\mathrm{C}$ & 8.45 & 2504 & & 380 & 16.89 & \\
\hline \multirow{3}{*}{0.58} & A & 8.70 & 2578 & \multirow{3}{*}{2588} & 278 & 12.36 & \multirow{3}{*}{14.85} \\
\hline & B & 8.50 & 2519 & & 366 & 16.27 & \\
\hline & $\mathrm{C}$ & 9.00 & 2667 & & 358 & 15.91 & \\
\hline \multirow{3}{*}{0.60} & $\mathrm{~A}$ & 8.65 & 2563 & \multirow{3}{*}{2558} & 248 & 11.02 & \multirow{3}{*}{9.90} \\
\hline & B & 8.75 & 2593 & & 182 & 8.09 & \\
\hline & $\mathrm{C}$ & 8.50 & 2519 & & 238 & 10.58 & \\
\hline
\end{tabular}

Table 5. Compressive strengths at 28 days for ORLS concrete (1:3:6 mix).

\begin{tabular}{|c|c|c|c|c|c|c|c|}
\hline $\begin{array}{l}\text { Water- } \\
\text { cement } \\
\text { ratio }\end{array}$ & Replicates & $\begin{array}{l}\text { Mass } \\
(\mathrm{Kg})\end{array}$ & $\begin{array}{l}\text { Density } \\
\left(\mathrm{Kg} / \mathrm{m}^{3}\right)\end{array}$ & $\begin{array}{l}\text { Average } \\
\text { density } \\
\left(\mathrm{Kg} / \mathrm{m}^{3}\right)\end{array}$ & $\begin{array}{l}\text { Failure } \\
\text { load } \\
(\mathrm{KN})\end{array}$ & $\begin{array}{c}\text { Compressive } \\
\text { strength } \\
\left(\mathrm{N} / \mathrm{mm}^{2}\right) \\
\end{array}$ & $\begin{array}{c}\text { Average compressive } \\
\text { strength } \\
\left(\mathrm{N} / \mathrm{mm}^{2}\right)\end{array}$ \\
\hline \multirow{3}{*}{0.5} & $\mathrm{~A}$ & 7.70 & 2281 & \multirow{3}{*}{2326} & 44 & 1.95 & \multirow{3}{*}{3.88} \\
\hline & B & 7.85 & 2326 & & 96 & 4.27 & \\
\hline & $\mathrm{C}$ & 8.00 & 2370 & & 122 & 5.42 & \\
\hline \multirow{3}{*}{0.53} & A & 7.45 & 2207 & \multirow[t]{3}{*}{2509} & 88 & 3.91 & \multirow{3}{*}{3.94} \\
\hline & B & 7.95 & 2356 & & 78 & 3.47 & \\
\hline & $\mathrm{C}$ & 7.70 & 2281 & & 100 & 4.44 & \\
\hline \multirow{3}{*}{0.55} & $\mathrm{~A}$ & 8.30 & 2549 & \multirow{3}{*}{2410} & 204 & 9.07 & \multirow{3}{*}{8.74} \\
\hline & B & 8.30 & 2459 & & 214 & 9.51 & \\
\hline & $\mathrm{C}$ & 7.70 & 2459 & & 172 & 7.64 & \\
\hline \multirow{3}{*}{0.58} & A & 8.25 & 2444 & \multirow{3}{*}{2504} & 116 & 5.16 & \multirow{3}{*}{8.56} \\
\hline & B & 8.75 & 2593 & & 254 & 11.29 & \\
\hline & $\mathrm{C}$ & 8.35 & 2474 & & 208 & 9.24 & \\
\hline \multirow{3}{*}{0.62} & $\mathrm{~A}$ & 7.75 & 2296 & \multirow{3}{*}{2326} & 62 & 2.76 & \multirow{3}{*}{3.11} \\
\hline & $\mathrm{B}$ & 7.70 & 2281 & & 88 & 3.91 & \\
\hline & $\mathrm{C}$ & 8.10 & 2400 & & 60 & 2.67 & \\
\hline
\end{tabular}


Table 6. Compressive strengths at 28 days for granite concrete (1:3:6 mix).

\begin{tabular}{|c|c|c|c|c|c|c|c|}
\hline $\begin{array}{c}\text { Water- } \\
\text { cement } \\
\text { ratio }\end{array}$ & Replicates & $\begin{array}{l}\text { Mass } \\
(\mathrm{Kg})\end{array}$ & $\begin{array}{l}\text { Density } \\
\left(\mathrm{Kg} / \mathrm{m}^{3}\right)\end{array}$ & $\begin{array}{l}\text { Average } \\
\text { density } \\
\left(\mathrm{Kg} / \mathrm{m}^{3}\right)\end{array}$ & $\begin{array}{c}\text { Failure } \\
\text { load } \\
(\mathrm{KN})\end{array}$ & $\begin{array}{c}\text { Compressive } \\
\text { strength } \\
\left(\mathrm{N} / \mathrm{mm}^{2}\right)\end{array}$ & $\begin{array}{c}\text { Average } \\
\text { compressive } \\
\text { strength } \\
\left(\mathrm{N} / \mathrm{mm}^{2}\right)\end{array}$ \\
\hline \multirow{3}{*}{0.5} & $\mathrm{~A}$ & 8.60 & 2548 & \multirow{3}{*}{2583} & 288 & 12.80 & \multirow{3}{*}{13.63} \\
\hline & B & 8.80 & 2607 & & 428 & 19.02 & \\
\hline & $\mathrm{C}$ & 8.75 & 2593 & & 204 & 9.07 & \\
\hline \multirow{3}{*}{0.53} & $\mathrm{~A}$ & 8.45 & 2504 & \multirow{3}{*}{2474} & 308 & 13.69 & \multirow{3}{*}{13.87} \\
\hline & B & 8.40 & 2489 & & 348 & 15.47 & \\
\hline & $\mathrm{C}$ & 8.20 & 2430 & & 280 & 12.44 & \\
\hline \multirow{3}{*}{0.55} & $\mathrm{~A}$ & 8.60 & 2548 & \multirow{3}{*}{2528} & 302 & 13.42 & \multirow{3}{*}{15.70} \\
\hline & B & 8.75 & 2593 & & 318 & 14.13 & \\
\hline & C & 8.25 & 2444 & & 440 & 19.56 & \\
\hline \multirow{3}{*}{0.58} & A & 8.55 & 2533 & \multirow{3}{*}{2519} & 318 & 14.13 & \multirow{3}{*}{16.15} \\
\hline & B & 8.45 & 2504 & & 378 & 16.48 & \\
\hline & $\mathrm{C}$ & 8.50 & 2519 & & 394 & 17.51 & \\
\hline \multirow{3}{*}{0.62} & A & 8.40 & 2489 & \multirow{3}{*}{2459} & 270 & 12.00 & \multirow{3}{*}{12.68} \\
\hline & B & 8.30 & 2459 & & 214 & 9.51 & \\
\hline & $\mathrm{C}$ & 8.20 & 2430 & & 372 & 16.53 & \\
\hline
\end{tabular}

The relationship between the two concrete produced at mix ratios 1:2:4 and 1:3:6 are presented in Figure 3 and Figure 4 respectively.

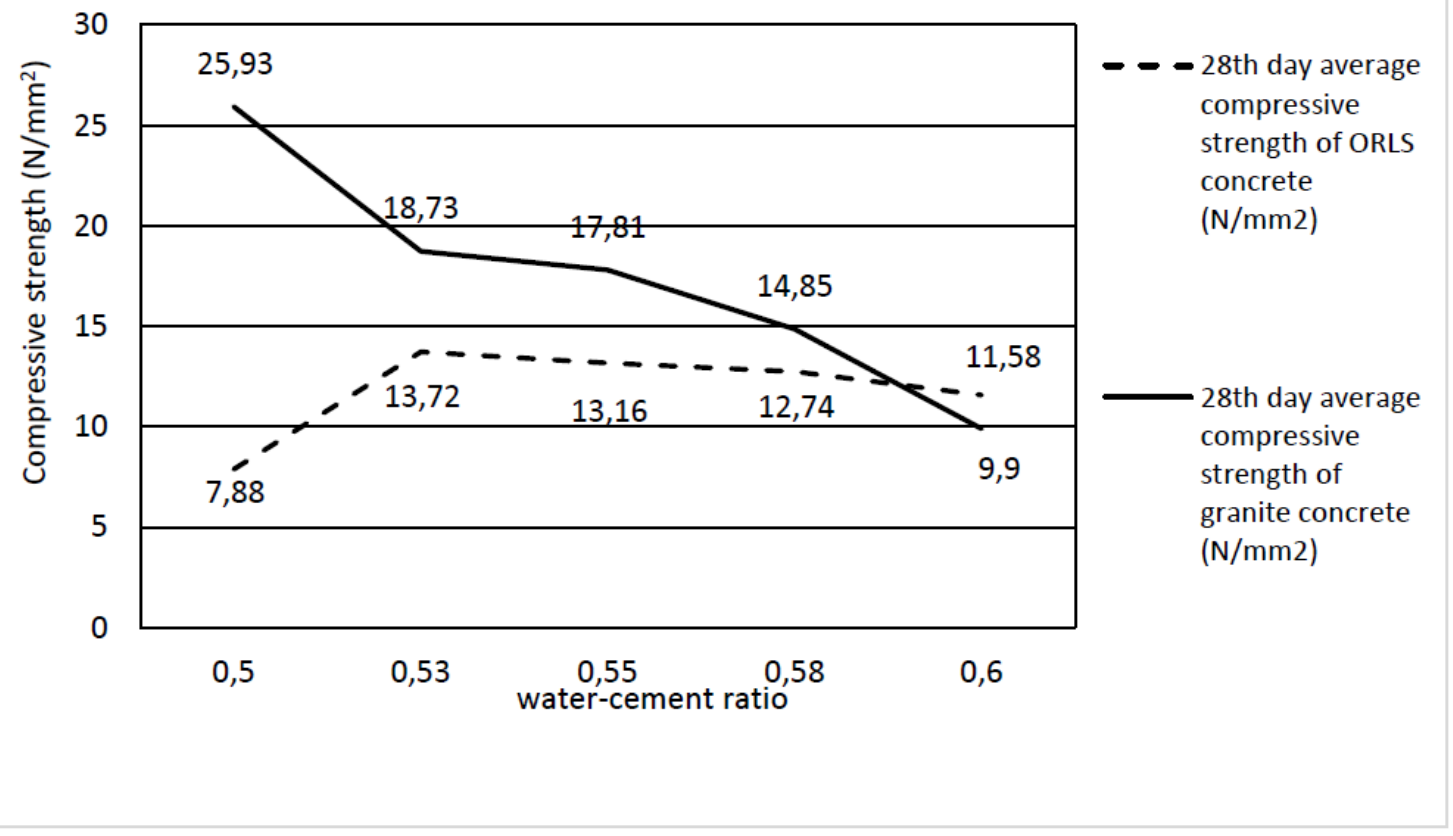

Fig. 3. Relationship between compressive strength $\left(\mathrm{N} / \mathrm{mm}^{2}\right)$ at 28 days and water-cement ratio of the two concrete types at mix ratio $1: 2: 4$. 


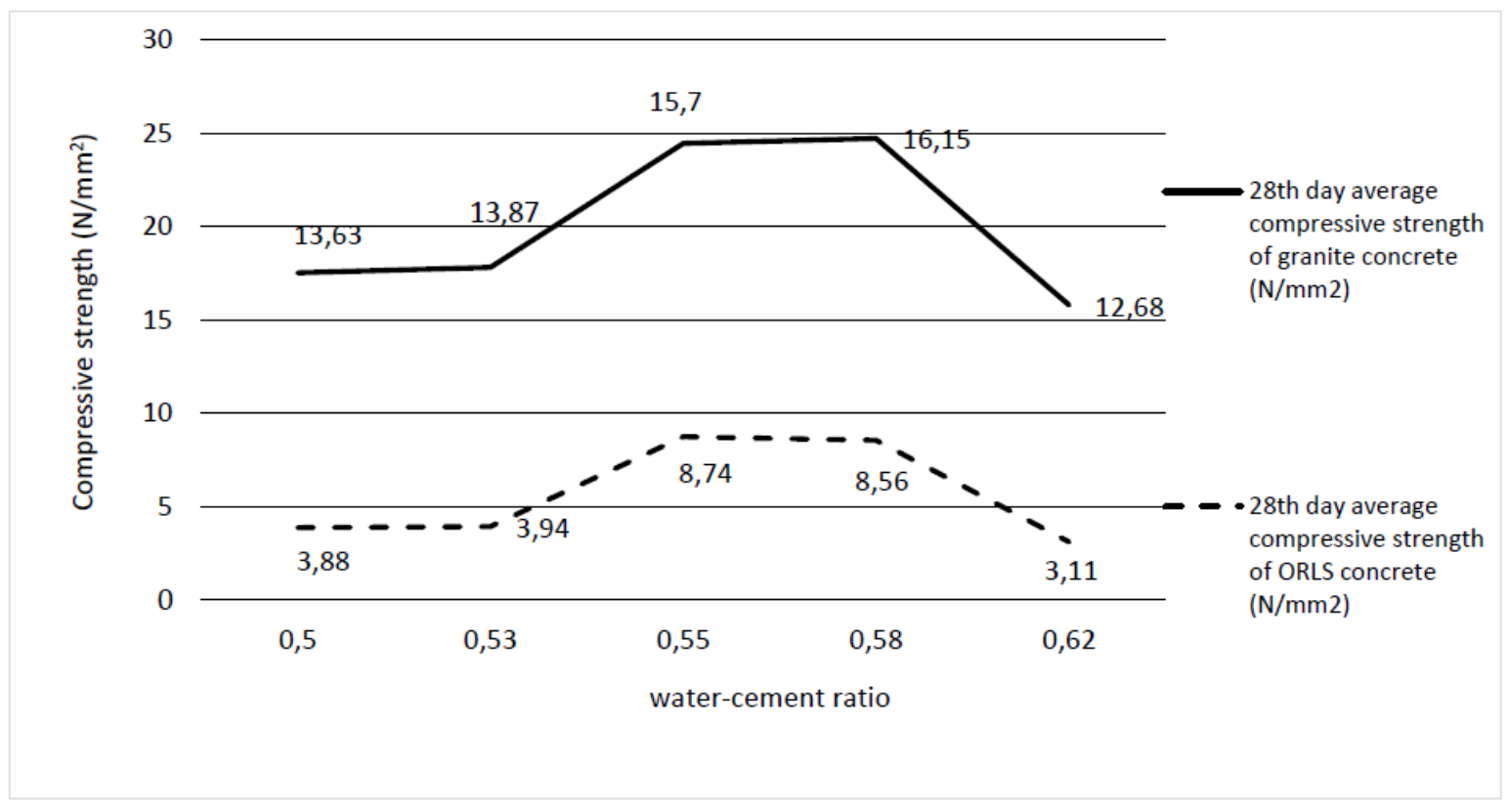

Fig. 4. Relationship between the compressive strength $\left(\mathrm{N} / \mathrm{mm}^{2}\right)$ at 28 days and water-cement ratio of the two concrete types at mix ratio 1:3:6.

\section{CONCLUSIONS}

Figure 1 and Figure 2 show the slump values recorded for concrete produced from granite chippings and the red lump stone. Concrete produced with granite chippings, experienced better workability than those produced with the local stone for the two mixes. This may be due to the fact that the local stone is more porous than granite chippings. When producing the concrete, some of the water moves to fill the pore spaces in the aggregate, while the remaining are left for the hydration process.

Table 3 and Table 5 shows that the maximum compressive strength values recorded for ORLS concrete were $13.72 \mathrm{~N} / \mathrm{mm}^{2}$ at water cement ratio of 0.53 for $1: 2: 4$ mix ratio; and $8.74 \mathrm{~N} / \mathrm{mm}^{2}$ at water-cement ratio of 0.55 for 1:3:6 mix ratio. This resulted to a difference of $56.98 \%$ between the mix ratios considered.

Figure 3 shows that at 1:2:4 mix ratio, the compressive strength of ORLS concrete increased as water-cement ratio was increased until a maximum value of $13.72 \mathrm{~N} / \mathrm{mm}^{2}$ was attained at water-cement ratio of 0.53 . Beyond this point, a reduction in strength was experienced as the water-cement ratio was further increased. This was not the case for the granite concrete. As the water-cement ratio was increased, the strength kept on decreasing. Maximum compressive strength reached was $25.93 \mathrm{~N} / \mathrm{mm}^{2}$ at 0.5 water-cement ratio. Further, it was observed that a tie in compressive strength value of about $12 \mathrm{~N} / \mathrm{mm}^{2}$ was achieved by the two concrete at a water-cement ratio of about 0.59 .

For the 1:3:6 mix ratio as shown in Figure 4, compressive strengths for both granite and ORLS concrete experienced an increase up to maximum points. Granite concrete reached a maximum compressive strength value of $16.15 \mathrm{~N} / \mathrm{mm}^{2}$ at 0.58 water cement ratio, while ORLS concrete attained a maximum compressive strength value of $8.74 \mathrm{~N} / \mathrm{mm}^{2}$ at water-cement of 0.55 .

At 0.6 water-cement ratio, it was observed that the compressive strength values of granite concrete was lower than that of ORLS concrete, with a percentage difference of $16.96 \%$ for mix ratio 1:2:4.

Comparing the maximum compressive strengths of ORLS for the two mix ratios investigated, it was observed that none of these values were up to $20 \mathrm{~N} / \mathrm{mm}^{2}$ which is the ACI 318 (1995) recommendation for a structural concrete. Also, for none structural concrete (e.g. lintels) using ORLS as coarse aggregate, mix 1:2:4 at watercement ratio of 0.53 is recommended. 


\section{REFERENCES}

[1] Shetty, M.S., Properties of concrete, Multicolour Revised edition, S. Chad \&Company Ltd., 2006.

[2] Neville, A.M., Properties of concrete (4th edition), Pearson Education Inc., 2006.

[3] Gupta, B.L., Gupta, A., Concrete technology (3rd Ed.), Standard Publishers Distributors, New Delhi, India, 2004.

[4] Abdullahi, M., Effect of aggregate type on compressive strength of concrete, Internatonal Journal of Civil \& Structural Engineering, vol 2, no. 3, 2012, p. 793-800.

[5] Tsado, T.Y., Comparative analysis of concrete strength using Igneous, Sedimentary and metamorphic rocks (Crushed granites, limestone and marble stone) as coarse aggregate, 2015. Retrieved in June, 2016 from http://www.academia.edu/11376738/A_comparative_analysis_of_concrete_strength_using_igneous_sedimentary _and_metamorphic_rocks_crushed_granite_limestone_and_marble_stone_as_coarse_aggregate.

[6] Ajamu, S.O., Ige, J.A., Effect of coarse aggregates size on the compressive strength and the flexural strength of concrete beam, International Journal of Engineering Research and Application, vol 5, no. 1, 2015 p. 67-75.

[7] Yaqub, M., Bukhari, I., Effect of size of coarse aggregate on compressive strength of high strength concrete, $31^{\text {st }}$ Conference on our World in concrete and structures, Singapore, 2006, Retrieved in, April 2016 from http://cipremier.com/100031052.

[8] Aginam, C.H., Chidolue, C.A., Nwakire, C., Investigating the effects of coarse aggregate types on the compressive strength of concrete, International Journal of Engineering Research and Applications vol. 3, no. 4, p.1140-1144. 2013. Retrieved in 2018 from https://pdfs.semanticscholar.org/ebef/84c9fbd5ebe30e6d022eb074063bd704fbca.pdf.

[9] Oyewole, O.O., Arilewola, S.S., Jimoh, A.A., Oyejobi, D.O., Effects of aggregate sizes on the physical and mechanical properties of concrete using artificial aggregates, Proceedings of pebble concrete compressive strength, Applied Mechanics and Materials, vol. 238, 2011, p.133-137.

[10] Xie, W., Jin, Y., Li, S., Experimental research on the influence of grain size of coarse aggregate on the influence of grain size of coarse aggregate on pebble concrete compressive strength, Applied Mechanics and Materials, vol. 238, 2012, p. 133-137.

[11] Kumar, R.P., Krishna, R.M.V., A Study on the effect of size of aggregate on the strength and sorptivity characteristics of cinder based light weight concrete, Research Journal of Engineering Sciences, vol. 1, no. 6, 2012, p. 27-35.

[12] Bhikshma, V., Florenc, G.A., Studies on effect of maximum size of aggregate in higher grade concrete with high volume fly ash, Asian Journal of Civil Engineering. vol. 14, no. 1, 2013, p. 101-109. Retrieved in April 2016

from

https://www.researchgate.net/publication/266501960_Studies_on_effect_of_maximum_size_of_aggregate_in_hi gher_grade_concrete_with_high_volume_fly_ash.

[13] Su, R.K.L., Cheng, B., The Effect of coarse aggregate size on the stress-strain curves of concrete, 2008.

[14] Anthony, W., Amoah, D.K., Ayuba, I., Ballow, P., The effect of maximum coarse aggregate size on the compressive strength of concrete, produced in Ghana, Civil and Environmental Research, vol. 7, no. 5, 2015 , p. $7-12$. 